\title{
İplik Üretim Sistemlerinin 1x1 Rib Kumaşların Boyutsal Parametrelerine Etkisi
}

\author{
Effect of Yarn Spinning Systems on Dimensional \\ Parameters of 1X1 Rib Fabrics \\ Serin Mezarcıöz' ${ }^{\oplus}$, R.Tuğrul Oğulata2® \\ ${ }^{1,2}$ Çukurova Üniversitesi, Mühendislik Fakültesi,Tekstil Mühendisliği Bölümü, Adana, TÜRKIYE \\ Sorumlu Yazar / Corresponding Author*: smavruz@cu.edu.tr
}

Geliş Tarihi / Received: 18.03.2020

Araștırma Makalesi/Research Article Kabul Tarihi / Accepted: 05.11.2020 DOI:10.21205/deufmd.2021236723

Atıf șekli/How to cite: MEZARCIÖZ, S., OĞULATA, R.T.(2021). İplik Üretim Sistemlerinin 1x1 Rib Kumașların Boyutsal Parametrelerine Etkisi. DEUFMD, 23(67), 265-275.

Öz

Bu çalışmada 1x1 rib örme kumaşların boyutsal parametreleri incelenmiştir. Kumaşların üretiminde; ring, kompakt ve open end rotor iplik üretim sistemlerinden üretilmiş farklı iplik numaralarında ve ilmek iplik uzunluğunda iplikler kullanılmıştır. Kumaşlara farklı relaksayon prosesleri uygulanmış ve $\mathrm{U}_{\mathrm{c}}, \mathrm{U}_{\mathrm{w}}$ and $\mathrm{U}_{\mathrm{s}}$ boyutsal parametreleri hesaplanmıştır. Sonuçlara göre 5 yıkama/kurutma devrinden sonra ilmekler tamamen relakse olmaktadır. İplik üretim sistemlerinden kaynaklanan yapısal farklılıklarının boyutsal parametreler üzerinde etkili olmadığı bulunmuştur. Ayrıca, R (ilmek şekil faktörü) değeri kumaş yapısal sıklık faktörünün artmasıyla lineer olarak artmaktadır.

Anahtar Kelimeler: 1x 1 rib örme kumaş, Boyutsal parametreler, Boyutsal sabitler, Relaksasyon

\begin{abstract}
In this study, dimensional parameters of $1 \mathrm{x} 1$ rib fabrics were examined. Fabrics of different yarn counts and stitch length values were produced from yarns obtained from ring, compact and rotor spinning systems. Three different relaxation processes were applied to these fabrics and dimensional parameter values (Uc, Uw and Us ) were calculated. According to the results of the study; after 5 washing / drying cycles, the loops were determined to be completely relaxed. It was found that the structural differences of the yarns obtained from different yarn production systems were not effective on dimensional parameters. Also, R (loop shape) values increases linearly with the increase of fabric structural tightness factor (STF).
\end{abstract}

Keywords: $1 \times 1$ rib fabrics, Dimensional parameters, Dimensional constants, Relaxation

\section{Introduction}

Due to the tensions caused by pulling the fabric during the knitting process, the length of the loop increases and the loop width decreases. This causes the shape change in the loop. The fabric naturally changes shape as the loops want to return to their natural shape after knitting. This change is defined as fabric relaxation [1]. Some 
of relaxation conditions defined in literature are described $[2,3,4,5,6,7]$.

It is imperative to control the dimensional changes starting from the raw fabric production in order to prevent the size change problem.

Studies on dimensional parameters of $1 \times 1 \mathrm{rib}$ knitted fabrics are given as follows.

The dimensional parameters of the rib knitted fabrics produced on a double jersey flat bed machine using acrylic yarn was investigated by Mukherjee, Ray and Punj (2012). Regression analyses and equations were generated to investigate the effect of loop length on courses and wales per $\mathrm{cm}$ at different relaxation stages [8].

The impact of the yarn linear density used the dimensional stability of the $1 \times 1$ rib knitwear made on same circular knitting machine was analyzed by Pesic et al., 2018. Raw knitwear samples are made from $100 \%$ cotton yarn with different linear densities of 19,17, 15 and 13 tex were used in the study [9].

When the studies in the literature are examined, it has been found that there are studies investigating the effect of different yarn counts, loop density or yarns made of different fibers on the dimensional parameters of knitted fabrics. In this study, the effects of different yarn production systems and different relaxation processes were statistically investigated. In order to investigate the effect of different yarn production systems on the loop parameters, 24 knitted fabrics were produced from the yarns spinning from ring, compact and open end-rotor yarn production systems in three different densities. Three different relaxation processes such as dry relaxation, washing and full relaxation were applied to the fabrics. After each relaxations; course density, wale density, loop yarn length and dimensional parameters of the fabrics were measured. SPSS statistical package program was used to analyze the values and the results were presented as follows.

\section{Geometry of knitted fabrics}

Gravas et al. (2006) indicated that, Munden $(1959,1960)$ has shown that the dimensions of plain knitted fabrics, in a state of minimum energy, are dependent only upon the length of the yarn knitted into each loop. His experimental studies have indicated that courses and wales per unit length and loop length are related to each other by constant as follows:

$K_{c}=$ cpixl

$K_{w}=$ wpixl

$K_{s}=S x l^{2}$

$K_{r}=R=\frac{c p i}{w p i}=\frac{K_{c}}{K_{w}}$

In the original publication, there is

$K_{2}=K_{c}, K_{3}=K_{w}, K_{1}=K_{s}, K_{4}=K_{r}=R$

In the above equations, cpi and wpi define the courses per inch and the wales per inch respectively. $S$ is the loop density, and is calculated by multiplying courses and wales per inch. Finally, $l$ is the loop length, which can be measured in inches, and $\mathrm{K}_{\mathrm{r}}$ or $\mathrm{R}$ is the loop shape $[4,10,11]$.

A theoretical approach on double-knitted structures was presented by Nutting \& Leaf [12], who introduced a constant value and a term concerning the yarn diameter on the basis of the equations 1 and 2 above, which can be written in the form:

$\frac{1}{C}=A l+D T^{\frac{1}{2}}$

where A and D are constants whose numerical values will depend on the fabric construction, $\mathrm{T}$ is the yarn tex value and $\mathrm{C}$ (or $\mathrm{W}$ ) refers to courses and wales per unit length respectively. The above equation indicates that yarn diameter is a significant factor in determining fabric dimensions, contrary to Munden's basic approach.

\section{Material and Method}

In this study, rib fabrics were knitted with three different tightness (slack, medium and tight) on a circular knitting machine (18 gauge, 34 "diameter, $1920 * 2$ total needle count, with a positive yarn feeding system) using ring, compact and open end rotor yarn spinning systems with different yarn numbers (11,8 tex, 14,8 tex, 19,7 tex and 29,5 tex). Yarn characteristic are shown in Table 1.

The following relaxation treatments were applied to fabrics after knitting.

Dry relaxation: Fabrics were placed on a flat surface for at least 24 hours in the standard atmosphere $\left(20 \pm 2{ }^{\circ} \mathrm{C}\right.$ temperature and $65 \pm 2 \%$ 
relative humidity). Washing relaxation: After dry relaxation, fabrics were washed in a domestic washer at $30^{\circ} \mathrm{C}$ min 45 using $0.05 \%$ wetting agent. After wetting, fabrics were briefly hydro extracted. Then they were conditioned in the same way as the dry relaxation method. Full relaxation: Washing relaxation procedure was repeated for five times. Before tests were taken, the fabrics were conditioned for $48 \mathrm{~h}$ in a standard atmosphere. As a result, 72 samples (24 - dry relaxation; 24 - washing relaxation; 24full relaxation) were used in total.

Loop length, wales per $\mathrm{cm}$, courses per $\mathrm{cm}$ were measured according to the relevant standards (TS EN 14970, 2006; TS EN 14971, 2006) [13, 14]. It was carried out that loop length measurements were realized only in dry relaxed fabrics since some researches determined that there was no change in loop length after wet relaxation processing, which is around $2 \%$ could be ignored $[15,16]$.

In this study, in order to determine the $\mathrm{U}$ constants, indicating the dimensional parameter values of the fabrics, the equations proposed by Jeddi and Zareian (2006) were used [17]. They suggested that the shape of structural knitted cell (Figure 1) is divided into two segments, one segment being the needle loop and two arms of two plain-type face loops of the cell. Another segment is the linking portions between face and back loops for rib fabrics.

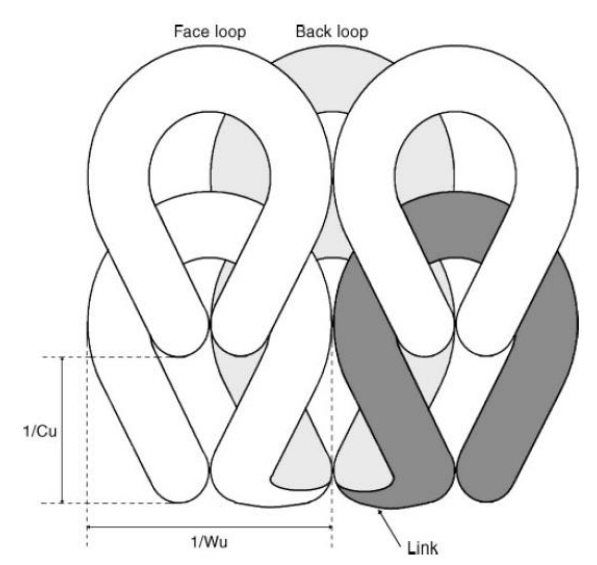

Figure 1 . The geometrical configuration of $1 \times 1$ rib structure [17].

From Figure 1, the maximum width and length of the structural knitted cell for $1 \mathrm{x} 1$ rib fabrics can be calculated similar to plain fabrics as follows:

$$
\begin{aligned}
& W_{u}=\frac{U_{w}}{L_{u}} \\
& C_{u}=\frac{U_{c}}{L_{u}} \\
& S_{u}=C_{u} \times W_{u}=\frac{U_{s}}{L_{u}^{2}}
\end{aligned}
$$

where $L_{u}$ is the length of yarn in SKC (structural knitted cell), $C_{u}$ courses/unit fabric length, $W_{u}$ wales/unit fabric width, $\mathrm{S}_{\mathrm{u}}$ the number of SKC's per unit area, and the "U values", $\mathrm{U}_{\mathrm{c}}, \mathrm{U}_{\mathrm{w}}$, and $\mathrm{U}_{\mathrm{s}}$ are dimensionless constants [17]. There are many influencing factors (fiber properties, knitting conditions, finishing, etc.) on the dimensional changes of rib fabrics. The values of $\mathrm{U}, \mathrm{Uc}, \mathrm{Uw}, \mathrm{R}$, are the values that the knitted fabric should have in the relaxation state. This relaxation state is when the bending energy on the yarn is minimal. These values relate in particular to loop length and loop density. When these values change, many factors such as appearance, air permeability may be affected along with the loop structure. 
DEÜ FMD 23(67), 265-275, 2021

Table 1. Yarn characteristics used for knitting

\begin{tabular}{|c|c|c|c|c|c|c|c|c|}
\hline \multirow[b]{2}{*}{ Parameter } & \multicolumn{3}{|c|}{ Conventional ring yarn } & \multicolumn{3}{|c|}{ Compact yarn } & \multicolumn{2}{|c|}{ Open end yarn } \\
\hline & 19,7 tex & 14,8 tex & 11,8 tex & 19,7 tex & 14,8 tex & 11,8 tex & 29,5 tex & 19,7 tex \\
\hline Evenness $U \%$ & 9.20 & 10.32 & 11.17 & 9.05 & 9.91 & 10.45 & 10.44 & 12.11 \\
\hline $\operatorname{CVm}(\%)$ & 11.60 & 13.03 & 14.13 & 11.40 & 12.50 & 13.20 & 13.13 & 15.23 \\
\hline Thin places $(-50 \%) / \mathrm{km}$ & 0.3 & 2.3 & 19.8 & 0.0 & 2.5 & 6.4 & 4.0 & 59.2 \\
\hline Thick places $(+50 \%) / \mathrm{km}$ & 7.1 & 22.7 & 54.9 & 6.6 & 14.7 & 37.6 & 21.9 & 75.3 \\
\hline Neps $(+200 \%) / \mathrm{km}$ & 63.1 & 97.2 & 200.0 & 10.7 & 29.2 & 54.6 & 0.8 & 16.1 \\
\hline Hairiness & 6.62 & 6.46 & 5.76 & 4.34 & 3.41 & 3.67 & 5.45 & 5.17 \\
\hline Breaking strength (gf/tex) & 354.1 & 234.4 & 174.0 & 381.9 & 294.7 & 241.4 & 361.7 & 226.2 \\
\hline Breaking elongation (\%) & 5.04 & 4.34 & 4.64 & 5.31 & 4.76 & 5.02 & 5.32 & 4.39 \\
\hline Rkm (kgf.Nm) & 17.51 & 15.63 & 15.14 & 18.88 & 19.81 & 19.66 & 12.00 & 11.03 \\
\hline Breaking work (gf.cm) & 482.7 & 277.5 & 220.2 & 535.6 & 381.1 & 318.1 & 528.8 & 283.2 \\
\hline
\end{tabular}

\section{Results}

Fabric properties and dimensional properties (yarn number, yarn type, loop length, $U_{c}, U_{w}, U_{s}$, $\mathrm{R}$ values) for rib fabrics in different relaxation states are presented in tabulated form in Table 2.
It can be seen that $U_{c}, U_{w}, R$ parameters seen in the table vary according to relaxation conditions and differ for some yarn types. In the previous studies, $U_{c}$ and $U_{w}$ values given by the researchers for $1 \mathrm{x} 1$ rib structures in the fully relaxed state are shown in Table $3[1,11]$. 
DEÜ FMD 23(67), 265-275, 2021

Table 2. Fabric properties and dimensional parameters for rib fabrics

\begin{tabular}{|c|c|c|c|c|c|c|c|c|c|c|c|c|c|c|}
\hline \multirow{2}{*}{$\begin{array}{l}\text { Sample } \\
\text { number }\end{array}$} & \multirow{2}{*}{$\begin{array}{l}\text { Yarn } \\
\text { type }\end{array}$} & \multirow{2}{*}{$\begin{array}{l}\text { Yarn } \\
\text { number } \\
\text { (tex) }\end{array}$} & \multicolumn{4}{|c|}{ Dry relaxation } & \multicolumn{4}{|c|}{ Washing relaxation } & \multicolumn{4}{|c|}{ Full relaxation } \\
\hline & & & $U_{c}$ & $U_{w}$ & $U_{s}$ & $\mathrm{R}$ & $U_{c}$ & $U_{w}$ & $U_{s}$ & $\mathrm{R}$ & $U_{c}$ & $U_{w}$ & $U_{s}$ & $\mathrm{R}$ \\
\hline $\mathrm{R} 1$ & \multirow{9}{*}{ Ring } & 19,7 & 8,92 & 5,44 & 24,26 & 1,64 & 10,44 & 6,42 & 33,52 & 1,63 & 10,22 & 6,52 & 33,38 & 1,57 \\
\hline $\mathrm{R} 2$ & & 19,7 & 8,68 & 5,78 & 25,06 & 1,5 & 10,06 & 6,36 & 31,98 & 1,58 & 10,06 & 6,58 & 33,14 & 1,53 \\
\hline R3 & & 19,7 & 7,88 & 6,28 & 24,78 & 1,25 & 9,86 & 6,28 & 30,96 & 1,57 & 9,74 & 6,4 & 31,18 & 1,52 \\
\hline $\mathrm{R} 4$ & & 14,8 & 8,1 & 5,4 & 21,88 & 1,5 & 9,72 & 6,04 & 29,4 & 1,61 & 9,72 & 6,38 & 30,96 & 1,52 \\
\hline R5 & & 14,8 & 8,1 & 5,78 & 23,38 & 1,4 & 9,6 & 6,24 & 29,94 & 1,54 & 9,82 & 6,02 & 29,54 & 1,63 \\
\hline R6 & & 14,8 & 8,34 & 6,22 & 25,92 & 1,34 & 9,46 & 6,72 & 31,76 & 1,41 & 9,82 & 6,22 & 30,56 & 1,58 \\
\hline R7 & & 11,8 & 8,82 & 4,9 & 21,6 & 1,8 & 10 & 5,64 & 28,16 & 1,77 & 10,1 & 5,88 & 29,68 & 1,72 \\
\hline R8 & & 11,8 & 8,2 & 5,46 & 22,36 & 1,5 & 9,5 & 5,96 & 28,28 & 1,6 & 9,82 & 6 & 29,52 & 1,64 \\
\hline $\mathrm{R} 9$ & & 11,8 & 7,7 & 6,22 & 23,92 & 1,24 & 9,24 & 5,92 & 27,34 & 1,56 & 9,36 & 6,16 & 28,8 & 1,52 \\
\hline R 10 & \multirow{9}{*}{ Compact } & 19,7 & 9,54 & 5,3 & 25,28 & 1,8 & 10,38 & 6,42 & 33,3 & 1,62 & 10,5 & 6,46 & 33,92 & 1,63 \\
\hline R11 & & 19,7 & 8,78 & 5,7 & 25,02 & 1,54 & 10,26 & 6,28 & 32,16 & 1,64 & 10,14 & 6,72 & 34,12 & 1,51 \\
\hline $\mathrm{R} 12$ & & 19,7 & 8,52 & 6,48 & 27,68 & 1,31 & 10,02 & 6,56 & 32,8 & 1,53 & 10,26 & 6,8 & 34,86 & 1,51 \\
\hline $\mathrm{R} 13$ & & 14,8 & 9,36 & 5,26 & 24,58 & 1,78 & 9,88 & 6,56 & 32,36 & 1,51 & 10,4 & 6,56 & 34,08 & 1,59 \\
\hline $\mathrm{R} 14$ & & 14,8 & 8,78 & 6,06 & 26,62 & 1,45 & 10,12 & 6,84 & 34,6 & 1,48 & 10 & 6,44 & 32,28 & 1,55 \\
\hline $\mathrm{R} 15$ & & 14,8 & 8,26 & 6,26 & 25,9 & 1,32 & 9,84 & 6,5 & 32,04 & 1,51 & 9,98 & 6,56 & 32,74 & 1,52 \\
\hline R16 & & 11,8 & 8,54 & 5,06 & 21,58 & 1,69 & 10,42 & 5,8 & 30,22 & 1,79 & 10,42 & 5,96 & 31 & 1,75 \\
\hline R17 & & 11,8 & 8,24 & 5,74 & 23,64 & 1,44 & 10,16 & 6,34 & 32,16 & 1,6 & 9,72 & 7,1 & 34,5 & 1,37 \\
\hline $\mathrm{R} 18$ & & 11,8 & 7,76 & 6,28 & 24,34 & 1,24 & 9,36 & 6,4 & 29,9 & 1,46 & 9,6 & 6,86 & 32,92 & 1,40 \\
\hline R19 & \multirow{6}{*}{$\begin{array}{l}\text { Open-end } \\
\text { rotor }\end{array}$} & 29,5 & 8,76 & 5,58 & 24,42 & 1,57 & 10,4 & 5,64 & 29,28 & 1,84 & 10,14 & 5,88 & 29,84 & 1,72 \\
\hline $\mathrm{R} 20$ & & 29,5 & 8,16 & 5,74 & 23,44 & 1,42 & 10,1 & 6,22 & 31,46 & 1,62 & 9,96 & 6,22 & 31,04 & 1,60 \\
\hline $\mathrm{R} 21$ & & 29,5 & 8,56 & 6,28 & 26,92 & 1,36 & 10 & 6,42 & 32,12 & 1,56 & 9,86 & 6,42 & 31,66 & 1,54 \\
\hline $\mathrm{R} 22$ & & 19,7 & 8,94 & 4,94 & 22,1 & 1,81 & 10,54 & 5,48 & 28,86 & 1,92 & 10,32 & 5,86 & 30,2 & 1,76 \\
\hline R23 & & 19,7 & 8,06 & 5,36 & 21,6 & 1,51 & 9,8 & 5,94 & 29,04 & 1,65 & 9,9 & 6,34 & 31,38 & 1,56 \\
\hline R24 & & 19,7 & 8,06 & 6,02 & 24,24 & 1,34 & 9,68 & 6,38 & 30,88 & 1,51 & 10,04 & 6,2 & 31,14 & 1,62 \\
\hline
\end{tabular}


Table 3. A comparison of $U_{c}$ and $U_{w}$ values for $1 \times 1$ rib structures in the fully relaxed state $[1,11$, $18,19]$

\begin{tabular}{|l|l|l|}
\hline Researcher & $U_{c}$ & $U_{w}$ \\
\hline Knapton et al. (1968) & 10,60 & 6,03 \\
\hline Natkanski (1967) & 10,7 & 6,32 \\
\hline Jeddi and Zareian (2006) & 10,34 & 6,52 \\
\hline Present work & $\mathbf{9 , 3 6 - 1 0 , 5 0}$ & $\mathbf{5 , 8 6 - 7 , 1 0}$ \\
\hline
\end{tabular}

As can be seen from the tables, $U_{c}, U_{w}$ values obtained for rib fabrics were determined close to the values given by the researchers. Therefore, it is possible to say that the fabrics reached full relaxation after the 5 th wash.

With the change of the relaxation condition, it can be seen that loop shape factor (R) is significiantly reduced as a result of achieving a stable condition. As Pesic et.all defined that with the increase of relaxation, the minimum energy is produced so that the loop cannot be changed further and occupies the envisaged state in the space [9].

It can be also concluded that $U_{s}$ values increase in the knitwear which is made of the thinner yarn (when evaluated for the same loop length values). It means that the loop reaches its stable state and it has a minimal ability to change the shape.

In general, previous researchers calculated the properties of either only one fabric knitted from a single type of yarn or yarns having the same fineness. The loop parameters obtained in this study were calculated for knitted fabrics of different numbers and different yarn types and thus more realistic results were obtained. In order to determine the effect of spinning system on ribana fabrics and dimensional parameters, variance analysis was performed. The results can also be seen in the Table 4 [20].

Table 4. Leven's test of equality of error variance

\begin{tabular}{|l|l|l|l|l|}
\hline & F & df1 & df2 & Sig. \\
\hline$U_{c}$ & 2,834 & 8 & 15 &, 039 \\
$U_{W}$ & 1,008 & 8 & 15 &, 470 \\
\hline
\end{tabular}

Tests the null hypothesis that the error variance of the dependent variable is equal across groups.

According to the table of test of equality of error variance since the sig. $<0,05$ for $U_{c}$ variances value is not homogeneous. However, since the sig. $>0,05$ for $U_{w}$ variances value is homogeneous. That's way for $U_{c}$ tamhane and for $U_{w}$ LSD tests results were considered (Table 4-5).

In the evaluations according to the spinning system, for $U_{c}$ values, no significant differences were observed between ring, compact and rotorspun yarns; for $U_{w}$ values only significant differences were determined between compact and other yarns (Table 5). According to these results, it is seen that spinning systems do not significant effects in dimensional parameters of 1 x1 rib fabrics. 
DEÜ FMD 23(67), 265-275, 2021

Table 5. Multiple comparisons

\begin{tabular}{|c|c|c|c|c|c|c|c|c|}
\hline \multirow{2}{*}{\multicolumn{2}{|c|}{$\begin{array}{l}\text { Dependent } \\
\text { variable }\end{array}$}} & \multirow{2}{*}{$\mathrm{I}(\mathrm{R})$} & \multirow{2}{*}{$\mathrm{J}(\mathrm{R})$} & \multirow{2}{*}{$\begin{array}{l}\text { Mean } \\
\text { difference } \\
(\mathrm{I}-\mathrm{J})\end{array}$} & \multirow{2}{*}{ Std.Error } & \multirow{2}{*}{ Sig. } & \multicolumn{2}{|c|}{ 95\% Confidence Interval } \\
\hline & & & & & & & $\begin{array}{l}\text { Lower } \\
\text { bound }\end{array}$ & $\begin{array}{l}\text { Upper } \\
\text { bound }\end{array}$ \\
\hline & \multirow[t]{6}{*}{ LSD } & \multirow[t]{2}{*}{ ring } & compact &,$- 1311^{*}$ & ,05295 & ,026 &,- 2440 &,- 0182 \\
\hline & & & open end &,- 0072 & 05921 & ,905 &,- 1334 & 1190 \\
\hline & & \multirow[t]{2}{*}{ compact } & ring & ,1311* & 05295 & ,026 & ,0182 & ,2440 \\
\hline & & & open end & ,1239 & 05921 &, 054 &,- 0023 & ,2501 \\
\hline & & \multirow[t]{2}{*}{ open end } & ring & 0072 & ,05921 & ,905 &,- 1190 & 1334 \\
\hline & & & compact &,- 1239 & ,05921 &, 054 &,- 2501 & ,0023 \\
\hline & \multirow[t]{6}{*}{ Tamhane } & \multirow[t]{2}{*}{ ring } & compact &,- 1311 & ,18194 & ,861 &,- 6160 & ,3537 \\
\hline & & & open end &,- 0072 & ,23348 & 1,000 &,- 6846 & ,6702 \\
\hline & & \multirow[t]{2}{*}{ compact } & ring & ,1311 & ,18194 & ,861 &,- 3537 & 6160 \\
\hline & & & open end & 1239 & ,23212 & ,939 &,- 5517 & ,7995 \\
\hline & & \multirow[t]{2}{*}{ open end } & ring & ,0072 & ,23348 & 1,000 &,- 6702 & 6846 \\
\hline & & & compact &,- 1239 & ,23212 & ,939 &,- 7995 & ,5517 \\
\hline \multirow{12}{*}{$U_{w}$} & \multirow[t]{6}{*}{ LSD } & \multirow[t]{2}{*}{ ring } & compact &,$- 1689 *$ & ,06007 & 013 &,- 2969 &,- 0408 \\
\hline & & & open end & ,0250 & ,06716 & ,715 &,- 1182 & ,1682 \\
\hline & & \multirow[t]{2}{*}{ compact } & ring & ,1689* & ,06007 & ,013 & ,0408 & 2969 \\
\hline & & & open end & ,1939* & ,06716 & ,011 & ,0507 & ,3370 \\
\hline & & \multirow[t]{2}{*}{ open end } & ring &,- 0250 & ,06716 & ,715 &,- 1682 & 1182 \\
\hline & & & compact & -,1939* & ,06716 & 011 &,- 3370 &,- 0507 \\
\hline & \multirow[t]{6}{*}{ Tamhane } & \multirow[t]{2}{*}{ ring } & compact & -,1689 & ,09756 & 283 &,- 4323 & 0945 \\
\hline & & & open end & ,0250 & 09430 & ,992 &,- 2441 & 2941 \\
\hline & & \multirow[t]{2}{*}{ compact } & ring & ,1689 & ,09756 & 283 &,- 0945 & ,4323 \\
\hline & & & open end & 1939, & 10995 & ,276 &,- 1085 & ,4963 \\
\hline & & \multirow[t]{2}{*}{ open end } & ring &,- 0250 & 09430 & 992 &,- 2941 & 2441 \\
\hline & & & compact & -,1939 & 10995 & ,276 &,- 4963 & 1085 \\
\hline
\end{tabular}




\section{Tightness factor variations}

Regarding rib knits, another aspect needs some clarification. This has to do with the cover factor, which is equivalent to the tightness factor. Munden (1962) suggested the following practical expression for the cover factor [21]:

$C F=\frac{1}{l \sqrt{N}}$

where $\mathrm{N}$ is the yarn count and $\mathrm{l}$ is the loop length in inches. Postle (1965) proposed the term "tightness factor (TF)" to describe such a formula and defined it as [22]:

$T F=\frac{\sqrt{t e x}}{l}$

where tex is the yarn linear density and $\mathrm{l}$ is the loop length. It was recommended that the loop length be presented in millimeters [11]. Nevertheless, some researches indicated that the loop length can be presented in centimeters [23, 24].

In considering the stitch densities, structure tightness factor (STF) has been defined, as given in equation (11).

$S T F=T F x K_{S}$

$K_{S}$ is stitch density constant.
The graph of loop shape parameter (R) against the fabric structure tightness factor (STF) for fabrics produced with ring, compact and open end yarn after dry and full relaxation are shown in Figure 2-4. Although the results after washing relaxation were not shown in figures, these were similar to the results after dry and full relaxation.

According to the Fig.2-4, $\mathrm{R}$ values increases linearly with the increase of fabric tightness. The best-fit regression line between $\mathrm{R}$ and STF for all relaxation treatments is (the number of sample:1)

\section{$\mathrm{STF}=50,4 \mathrm{R}+115,89$}

with the correlation coefficient (r) of 0,9931 . R for the knitted fabrics is dependent on the fabric tightness. It has been determined that $R$ value depends on relaxation type especially in fabrics produced from ring yarns. In knitted fabrics with thin yarns produced by ring, compact and open end systems, the values of $R$ at the same fabric tightness increase with relaxation treatment (dry relaxation $<$ full relaxation).

In general, the relationship between STF and R for the same yarn counts in fabrics produced from all three yarn types was quite similar. Especially for fabrics made from ring and compact yarns, the graphical curves are very similar. In this case, it can be said that the loop parameters in the knitted fabrics are influenced by the relaxation type and yarn count rather than the yarn production type.

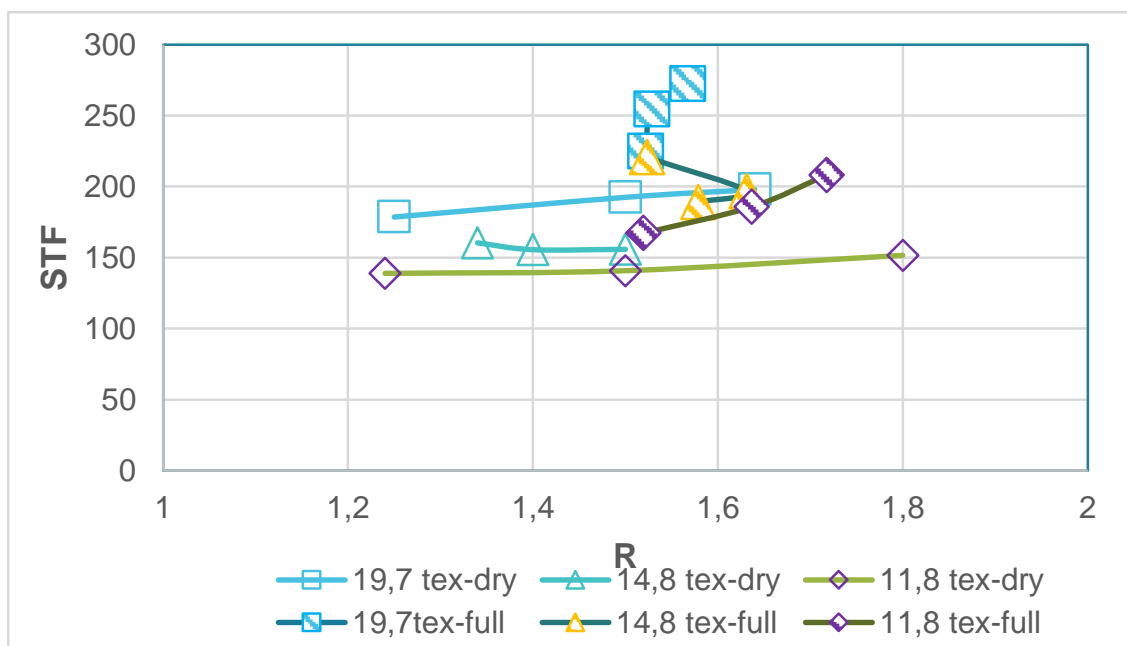

Figure 2. The graph of loop shape parameter (R) against the fabric structure tightness factor (STF)for ring yarns 
DEÜ FMD 23(67), 265-275, 2021

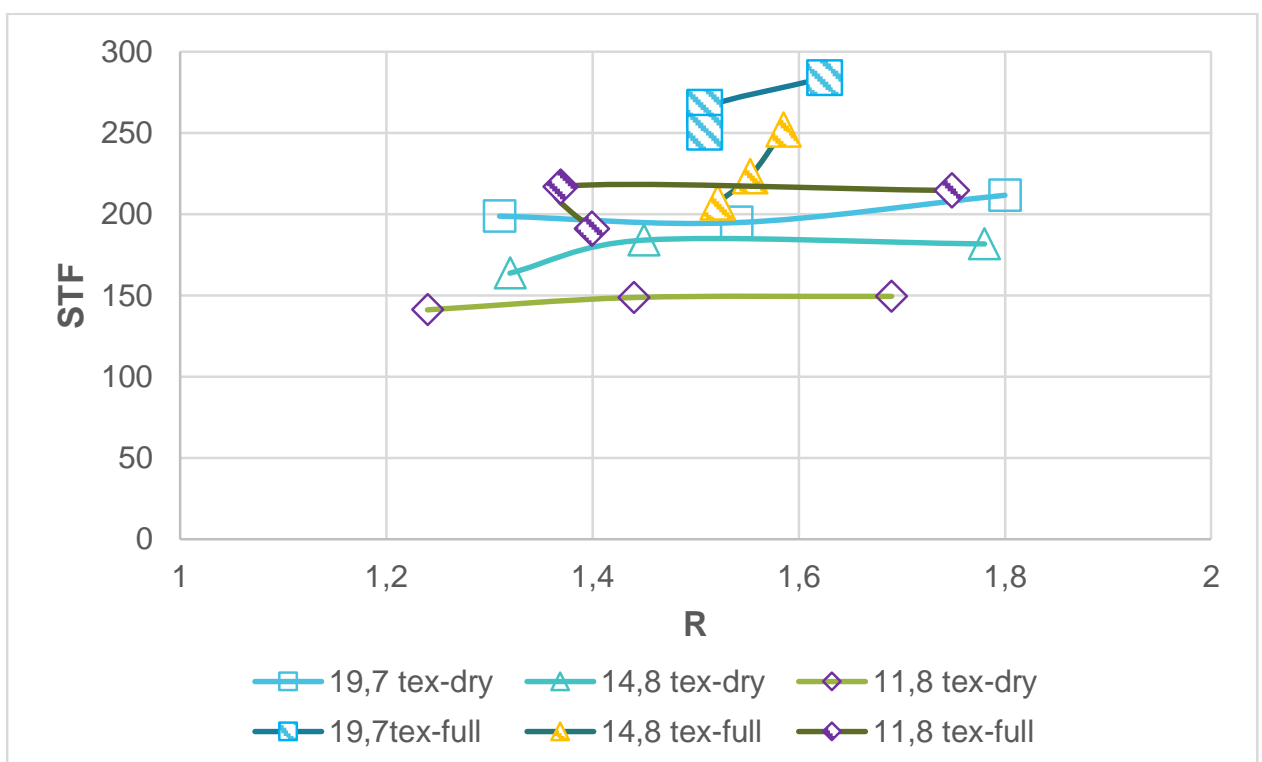

Figure 3. The graph of loop shape parameter (R) against the fabric structure tightness factor (STF)for compact yarns

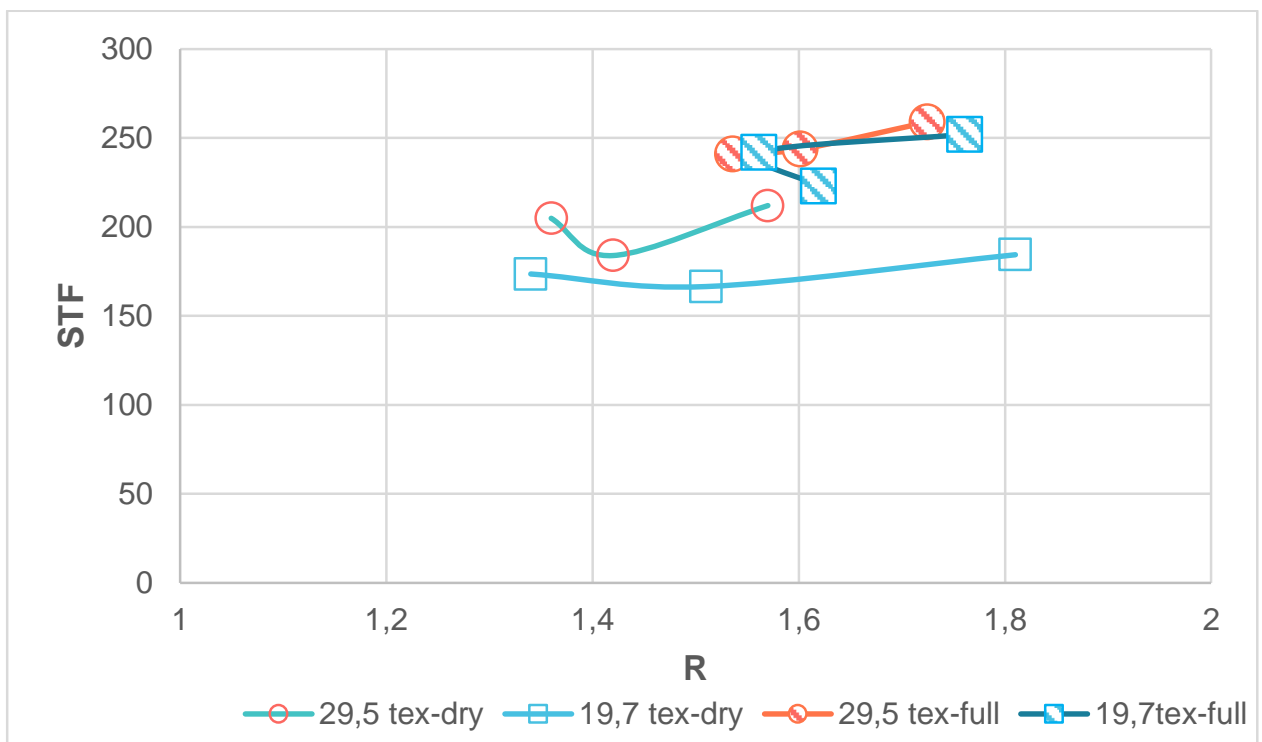

Figure 4. The graph of loop shape parameter (R) against the fabric structure tightness factor (STF)for open end rotor yarns

\section{Discussion and Conclusion}

In this article, different from previous studies, the effect of different yarn production systems and relaxation processes on the dimensional parameters of $1 \times 1$ rib knitted fabrics was examined. The values of dimensional knitting constants such as course constant $\left(U_{c}\right)$, wale constant $\left(\mathrm{U}_{\mathrm{w}}\right)$, stitch density constant $\left(\mathrm{U}_{\mathrm{s}}\right)$ and loop shape factor (R), obtained in $241 \times 1 \mathrm{rib}$ fabric samples made on circular knitting machine with different yarns by produced different yarn spinning systems and different 
yarn numbers. 72 samples (24 - dry relaxation; 24 - washing relaxation; 24 - full relaxation) were used in total.

The loop shape factor values obtained were very similar to the classical values reported by a number of previous researchers for fully relaxed fabrics. This confirmed that the loops had taken up their fully relaxed dimensions after five wash cycles.

In the evaluations according to the spinning system, it was seen that spinning systems do not significant effect in dimensional parameters of $1 \times 1$ rib fabrics.

The values of $U_{s}$ and $U_{w}$ increase progressively from dry relaxed state to washing relaxed state. This signifies that on subsequent relaxation process the fabric undergoes progressive widthwise shrinkage, resulting in decrease in the walespacing.

It can be also concluded that values $U_{c}$ and $U_{w}$ increase in the knitwear which is made of the thinner yarn generally. $\mathrm{R}$ decreases with the increase of relaxation which means that the loop reaches its stable state and it has a minimal ability to change the shape. Also $\mathrm{R}$ value rises significantly with the increase of the STF.

\section{References}

1. Marmaralı, A. 2004. Atkı Örmeciliğine Giriş. Ege Üniversitesi Tekstil ve Konfeksiyon Araştırma-Uygulama Merkezi Yayını. Yayın no:9, İzmir, $158 \mathrm{~s}$.

2. Ehrmann, A., Heimlich, F., Brücken, A., Weber, MO., Blachowicz, T. 2012. Experimental Investigation of the Washing Relaxation of Knitted Fabrics from Polyester Yarn with Stainless Steel Fibres, Fibres \& Textiles in Eastern Europe, Vol.20, (1), 90-93.

3. Sanjari, HR., Semnani, D., Sheikhzadeh, M. 2011. Investigating the Performance of Various Relaxation Processes on the Surface Regularity and Dimensional Properties of Plain Knitted Fabrics Using the Image Processing Technique, Fibres \& Textiles in Eastern Europe, Vol.19(2) (85), 36-42.

4. Munden, DL. 1959. The Geometry and Dimensional Properties of Plain-knit Fabrics, Journal of the Textile Institute, Vol. 50,448-471.DOI: $10.1080 / 19447025908659923$
5. Knapton, J.J.F., Truter, EV., Aziz, AKM, A. 1975. The Geometry, Dimensional Properties, and Stabilization of the Cotton Plain-Jersey Structure, J. Text. Inst, Vol.66(12),413-419. DOI: $10.1080 / 00405007508630536$

6. Quaynor, L., Nakajima, M., Takahashi, M. 1999. Dimensional Changes in Knitted Silk and Cotton Fabrics with Laundering, Textile Research Journal, Vol.69(4): 285291. DOI:10.1177/004051759906900408

7. Quaynor, L., Takahashi, M., Nakajima, M. 1998. Effect of Laundering on Bending Properties of Plain-Knitted Fabrics, J. Text. Mach. Soc. Japan (English Ed.), Vol.44(4), 74-77. DOI:10.4188/jte1955.44.74

8. Mukherjee, S., Ray, SC., Punj, SK. 2012. A Study on Dimensional Parameters of $1 \mathrm{x} 1$ Rib Fabric Produced on a Flat Bed Double Jersey Knitting Machine Using Ultrasonic Technique, Indian Journal of Fibre\&Textile Research, Vol. 37, 60-67.

9. Pešić, M., Petrović, V., Joksimović, D., Milosavljević, A. 2018. The Analysis of Dimensional Stability of $1 \mathrm{x} 1$ Rib Cotton Knitwear, Advanced Technologies, Vol. 7(2),63-67. DOI:10.5937/SavTeh1802063P

10. Munden, DL. 1960. Dimensional Stability of Plain Knit Fabrics, Journal of the Textile Institute, Vol.51,200-209. DOI:10.1080/19447016008664427

11. Gravas, E., Kiekens, P., Langenhove, LV. 2006. Predicting Fabric Weight per Unit Area of Single and Double Knitted Structures Using Appropriate Software, AUTEX Research Journal, Vol.6(4), 223237.

12. Nutting, TS., Leaf, G.A.V. 1964. Generalized Geometry of Weft-Knitted Fabrics, J. Textile Inst, Vol. 55, 45-53. DOI:10.1080/19447026408660207

13. TS EN 14970. Textiles: Knitted fabrics Determination of stitch length and yarn linear density in weft knitted fabrics. 2006. Ankara: Turkish Standards Institution.

14. TS EN 14971. Textiles: Knitted fabrics Determination of number of stitches per unit length and unit area. 2006. Ankara: Turkish Standards Institution.

15. Ceken, F., Goktepe, F. 2005. Comparison of the Properties of Knitted Fabrics Produced by Conventional and Compact Ring-spun 
Yarns, Fibres \& Textiles in Eastern Europe, Vol.13, No.1(49), 47-50.

16. Marmarali, A.B. 2003. Dimensional and Physical Properties of Cotton/spandex Single Jersey Fabrics, Textile Research Journal, Vol.73 (1),11-14. DOI:10.1177/004051750307300102

17. Jeddi, A.A.A., Zareian, A. 2006. Ideal Model for $1 \times 1$ Rib Fabric Taking Into Account Yarn Swelling: Guidelines for the Use of Ultrasonic Relaxation, The Journal of The Textile Institute, Vol.97(6),475-482. DOI:10.1533/joti.2005.0196

18. Natkanski, K.B. 1967. The Geometry and Dimensional Properties of the $1 \times 1 \mathrm{Rib}$ Knitted Structure, (Doctoral dissertation), Leeds University, Leeds, United Kingdom.

19. Knapton, J.J.F., Ahrens, F.J., Ingenthron, W.W., Fong, W. 1968. The Dimensional Properties of Knitted Wool Fabrics. Part 1: The Plain Knitted Structure, Textile Research Journal, Vol.38, 999-1012. DOI:10.1177/004051756803801004

20. SPSS 22.0 Statistical Package Program.

21. Munden, D.L. 1962. Specification of Construction of Knitted Fabrics. Journal of the Textile Institute, Vol. 53, 628-630. DOI:10.1080/19447016208688805

22. Postle, R. 1965. The Geometry of the Relaxed Plain-knit Structure. (Doctoral dissertation), Leeds University, Leeds, United Kingdom

23. Cheng, K.P.S., Yu, C. 2003. A Study of Compact Spun Yarns, Textile Research Journal, Vol.73, 345-349. DOI:10.1177/004051750307300412

24. Oinuma, R., Takeda, H. 1988. Spirality in Plain-Jersey Fabrics Knitted of Three-ply Cotton Yarns, Journal of the Textile Machinery Society of Japan, Vol.34, 74-78. DOI: $10.4188 /$ jte1955.34.74 